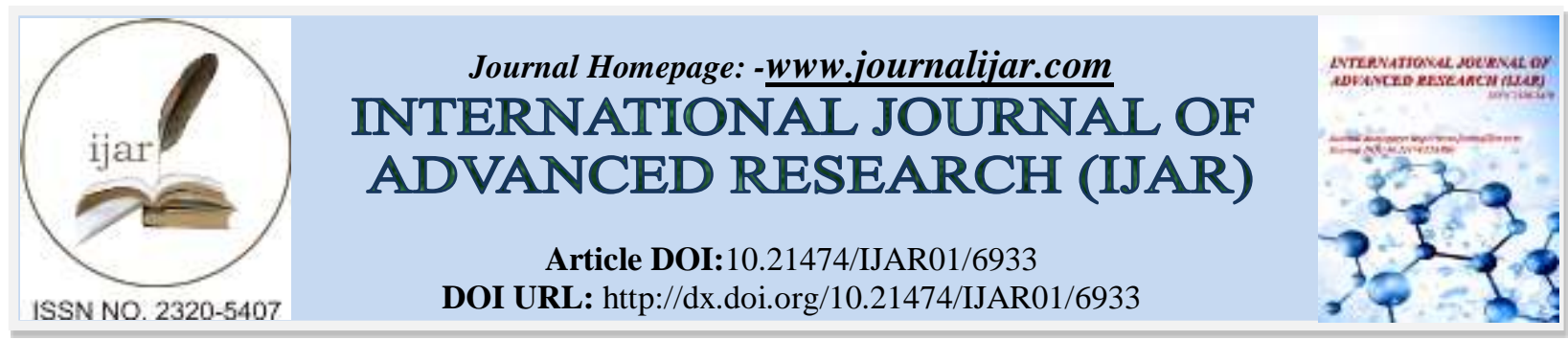

RESEARCH ARTICLE

\title{
EFFECTIVITY OF ETHANOLIC EXTRACTS FROM JAMBULANG FRUIT (SYZIGIUM CUMINI. L) AS ULTRAVIOLET ANTI RADIATION AGENT.
}

\author{
Zulkifli Zam Zam ${ }^{1}$, Dian Juniyanti ${ }^{2}$ and Khusna A. Rakhman ${ }^{3}$. \\ Chemistry Education Department of Universitas Khairun Jl. Bandara Babullah P.O.Box 53 Akehuda Ternate 97721, \\ North Maluku, Indonesia.
}

\section{Manuscript Info}

Manuscript History

Received: 13 February 2018

Final Accepted: 15 March 2018

Published: April 2018

Keywords:-

Jambulang Fruit (Syzigium Cumini L),

Ethanolic Extract, Ultraviolet Anti

Radiation Agent.

\begin{abstract}
This study aims to determine the effectiveness of ultraviolet antiradiation agents on Jambulang ethanolic extract (Syzigium Cumini L) by calculating SPF, $\% \mathrm{~T}$, and\% $\mathrm{Tp}$ values in UV A and UV B wavelengths with concentration variation of $1 \mathrm{ppm}, 10 \mathrm{ppm}, 100 \mathrm{ppm}$ and $1000 \mathrm{ppm}$. The preparation of jamblang fruit extract was done by maceration method using ethanol solvent. Measurement of absorbance value of the extract is by using UV-Vis spectrophotometer. The measurement result calculates SPF, $\% \mathrm{Te}$, and $\% \mathrm{Tp}$. The calculation results show the wavelength of UV A with concentration of $1 \mathrm{ppm}, 10$ ppm, $100 \mathrm{ppm}$, and $1000 \mathrm{ppm}$, where\% Tp in the sunblock category has the value of $1.129 ; 1,126 ; 1,138 ; 1,142$ and SPF with minimum protection category at concentration $1 \mathrm{ppm}$ and $10 \mathrm{ppm}$ has the value equal to 3,311 and 3,758 , medium protection at concentration $100 \mathrm{ppm}$ has the value equal to 4,989 and ultra protection at concentration 1000 ppm has the value equal to 315,5 . UV B with\% Te in the ultraprotection category has the value of $1.133 ; 1,158 ; 1,232 ; 2,731$ and SPF with minimum protection category at concentration $1 \mathrm{ppm}$ and $10 \mathrm{ppm}$ has the value equal to 2,280 and 2,979, moderate protection at concentration $100 \mathrm{ppm}$ has the value equal to 5,346 and ultra protection at concentration $1000 \mathrm{ppm}$ has the value equal to 13002 .
\end{abstract}

Copy Right, IJAR, 2018,. All rights reserved.

\section{Introduction:-}

Ultraviolet radiation can be divided into three kinds, namely UV-A radiation with a wavelength of 320-400 nm, UVB radiation of 280-320 $\mathrm{nm}$ and UV-C radiation of 100-280 nm (Nuverry, 2012). UV-A radiation has a longer wavelength compared to UV-B and UV-C, but has a smaller energy so the shorter the wavelength the higher the hazard (Rini, 2014). Many ways have been done to prevent the negative impact of UV radiation, one of them by using anti-radiation agent UV. These compounds utilized chemical molecules as anti-ultraviolet radiation capable of absorbing and deflecting ultraviolet radiation to protect human skin health from the negative impact it generates (Lavi, 2012). Products that produced are found in various forms, there are shaped powders, gels, lotions, and cream. These products then have side effects from their synthetic ultraviolet anti-radiation compounds, therefore, some formulations are now emerging by utilizing active compounds derived from plants as ultraviolet anti-radiation agents. Plants have photoprotective natural substances that can be extracted, this is associated with the ability of plants to receive sun exposure because plants need sun for photosynthesis (Prasidda, et al., 2016). It provides an 
overview of the ability of plants to protect the skin through compounds contained in the plant in the form of bioactive compounds such as phenolic and supported by the antioxidant compounds (Purwaningsish, et al., 2015). Antioxidant compounds are molecules from the synthesis of plants that can be used as an antidote to free radicals. Several classes of active antioxidant compounds such as flavanoid, tannin, anthraquinone, cinnamon, xanton have been tested and can be used to reduce UV radiation (Susanti, et al., 2012). Frans., Et al (2016) also tested the activity of anthocyanin, flavanoid, and polyphenol compounds that could potentially be used as antioxidants in red grapes (Vitis vinifera). Jamblang fruit (Syzigium Cumini L) is a local fruit that has a sense of acid sprinkling. Lia., Et al. (2014) reported that there is antioxidant activity in the extract of the fruit so it potentially serves as ultraviolet anti-radiation agent. Jamblang fruit is one of many plants in eastern Indonesia. This research was conducted to know the effectivity of Jambulang ethanolic extract as anti ultraviolet radiation agent.

\section{Materials And Methods:-}

Tools and materials:-

Jamblang fruit is cut small and then dried in an oven at $50^{\circ} \mathrm{C}$, weighed 100 grams and macerated with ethanol for 24 hours. After that, the filtrate that has obtained is concentrated by using rotary evaporator. Measured absorbance was performed at the wavelength range of $290-320 \mathrm{~nm}$ and $320-375 \mathrm{~nm}$, with intervals of $5 \mathrm{~nm}$ and 3 repetitions. The effectiveness of UV anti-ray agents can be measured by determining the SPF (sun protection factor) value, the percentage of erythema transmission and pigmentation transmission in absorbance are obtained from concentrations of $1 \mathrm{ppm}, 10 \mathrm{ppm}, 100 \mathrm{ppm}$ and $1000 \mathrm{ppm}$ at wavelengths 290-320 nm and $320-375 \mathrm{~nm}$ using a UV-Vis spectrophotometer.

\section{Data analysis technique:-}

The data were obtained by UV-Vis spectrophotometer at wavelength 320-400 nm, and 290-320 nm in determining absorbance of ethanolic extract of jamblang fruit. Measuring the effectiveness of a UV anti-ray agent can be done by determining, the SPF value, the percentage of erythema transmysis (\% Te), and percentage of pigmentation transmission (\% Tp) of spectrophotometric absorbance (Balsam 1972 and Jellinek 1970); \% $\boldsymbol{T} \boldsymbol{e}=\frac{\boldsymbol{E} \boldsymbol{e}}{\sum \boldsymbol{F e}}=\frac{\sum(\boldsymbol{T} \boldsymbol{x} \boldsymbol{F})}{\sum \boldsymbol{F} \boldsymbol{e}}$ dan $\% \boldsymbol{T} \boldsymbol{p}=\frac{\boldsymbol{E} \boldsymbol{p}}{\sum \boldsymbol{F} \boldsymbol{p}}=\frac{\sum(\boldsymbol{T} \boldsymbol{x} \boldsymbol{p} \boldsymbol{p})}{\sum \boldsymbol{F} \boldsymbol{p}}$. The SPF value (Sun Protection Factor) is determined by first calculating [AUC] $=$ $\frac{A \boldsymbol{a}+\boldsymbol{A b}}{2} \boldsymbol{x} \mathbf{d P a}-\mathbf{b}$, where: AUC $=$ area under curve, Aa = absorbance at wavelength a nm, Ab = absorbance at length wave $b \mathrm{~nm}$ and $\mathrm{dPa}-\mathrm{b}=$ wavelength difference $\mathrm{a}$ and $\mathrm{b}$. Next the SPF value of each concentration is determined by using the equation, $\log \boldsymbol{S P F}=\left[\frac{\boldsymbol{A U C} \boldsymbol{C}}{\lambda n-\lambda l}\right] \boldsymbol{x} 2$, where: $\lambda \mathrm{n}=$ largest wavelength, $\lambda 1=$ smallest wavelength, $\mathrm{n}-1=$ eryemogenic interval. Valuing category of UV radiation agent is based on\% Te and\% Tp, Balsam (1972). For the category of UV Radiation Agent value is based on SPF (Sun Protection Factor).

\section{Results And Discussion:-}

Jamblang fruit (Syzigium Cumini L.) that used in this study is fruit with blackish red colour. Sample preparation is done by washing and draining the sample, then removing the water content in the fruit by heating the sample at $50{ }^{\circ} \mathrm{C}$ for 7 days. 100 grams of Jamblang fruit are macerated in $500 \mathrm{~mL}$ of ethanol solvent for 1 x 24 hours. The extract is then concentrated with a rotary vacuum evaporator to remove the solvent content in the sample to obtain a pure extract. Subsequently the sample is dissolved in ethanol with concentration variations of $1000 \mathrm{ppm}, 100 \mathrm{ppm}, 10$ ppm, and $1 \mathrm{ppm}$. the selection of this variation is done by looking at the valid UV Vis spectrophotometer capability that is at absorption value $>0$ and $<1$. To know the effectivity of uv anti-radiation agent from simplicia, this research is done in vitro using spectrophotometric method. The effectiveness of the uv anti-ray agent can be seen from the $\%$ $\mathrm{Te}, \% \mathrm{Tp}$ and SPF values. The higher the SPF value and the lower. value of $\% \mathrm{Te}$, and.\% Tp then the better the protection of the UV anti-ray agent.

The determination of $\% \mathrm{Te}$, and $\% \mathrm{Tp}$ values used the transmittance value at $5 \mathrm{~nm}$ interval, where $\% \mathrm{Tp}$ at $\mathrm{UV}$ wavelength $\mathrm{A}$ and $\mathrm{Te} \%$ on UV length $\mathrm{B}$, the result of measurement is then processed using Balsam equation. Calculation of SPF value used absorbance value with interval 5 at wavelength UV A and UV B, from absorbance measurement data then processed by calculating the value of AUC and inserted into Petro equation. Measurement of ethanolite extract was done with variation of concentration, 1 ppm, 10 ppm, 100 ppm, 1000 ppm. Blanks that used in the measurements are adjusted with the solvent during maceration. Variations of concentration were done to determine the optimum concentration value in providing protection from UV exposure. 
Table 1:-SPF, Te\% and \% Tp Value data at UV A and UV B wavelengths

\begin{tabular}{|c|c|c|c|c|}
\hline $\begin{array}{c}\text { Concentration } \\
(\mathbf{p p m})\end{array}$ & UV A & UV B & \multirow{2}{*}{ \% Te } & \multirow{2}{*}{ \% Tp } \\
\cline { 2 - 4 } & 3,311 & 2,280 & 1,133 & 1,129 \\
\hline 1 & 3,758 & 2,979 & 1,158 & 1,126 \\
\hline 10 & 4,989 & 5,346 & 1,232 & 1,138 \\
\hline 100 & 315,5 & 13.002 & 2,731 & 1,142 \\
\hline
\end{tabular}

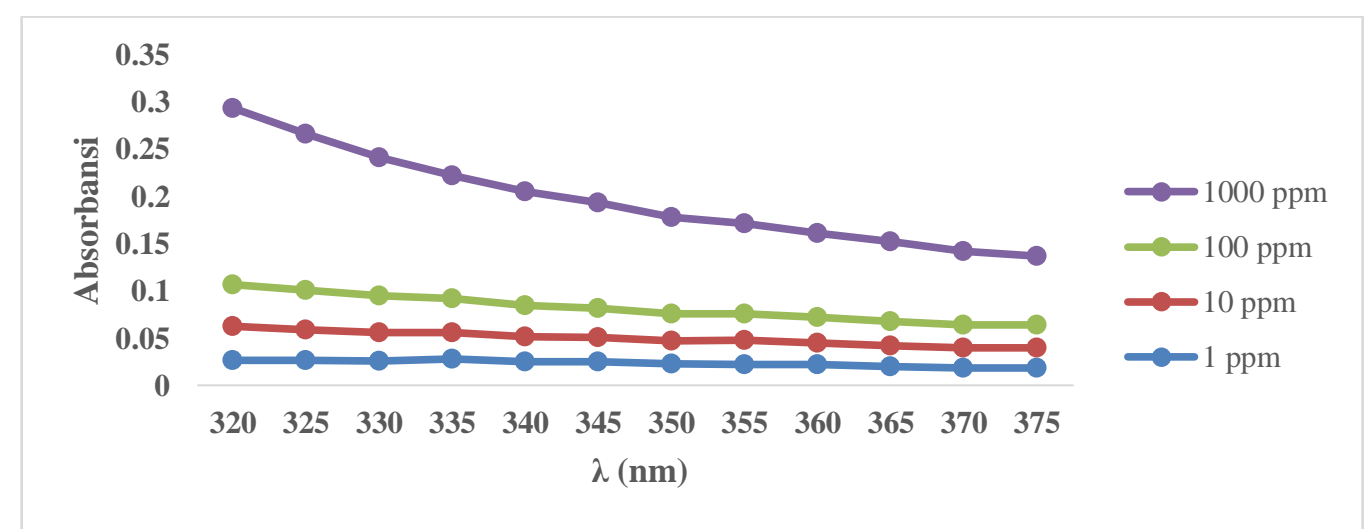

Figure 1:-Absorbance value of ethanolite extract of jamblang fruit at UV-A wavelength

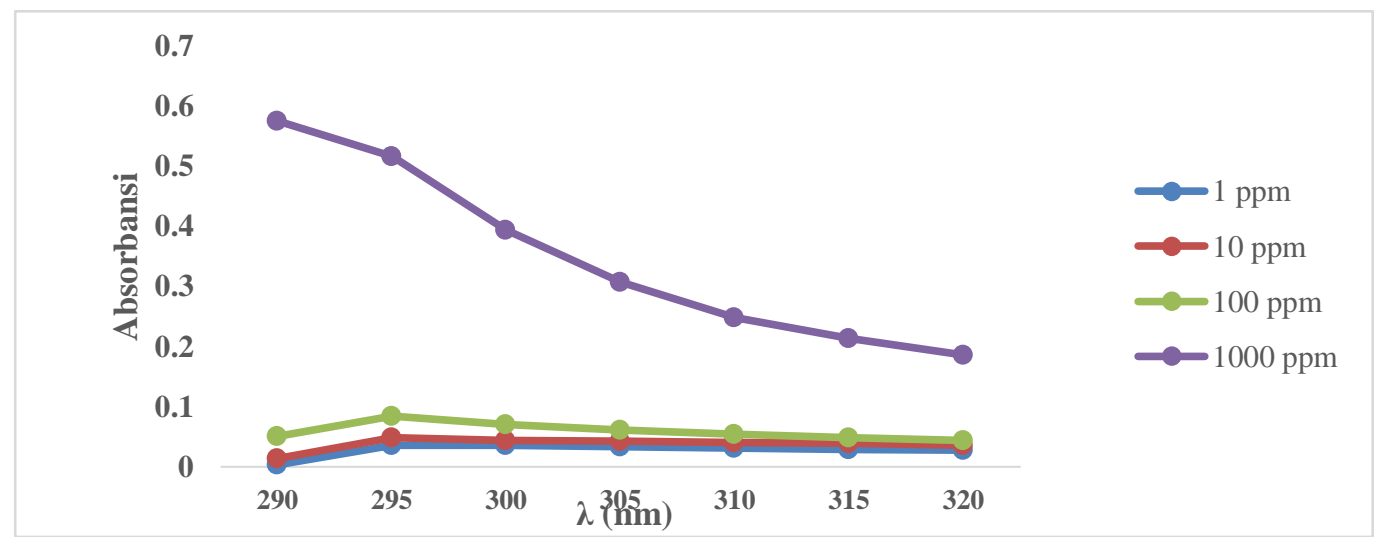

Figure 2:-Absorbance value of ethanolite extract of jamblang fruit at UV-B wavelength

The graphs in Figure 1 and 2 show that the concentration is directly proportional to the absorbance where the higher the concentration, the absorbance value is also higher in accordance with the law of lambert beer. Measurement of absorbance at UV A wavelength with variation of concentration show that ethanolite extract of jamblang had highest absorbance at $320 \mathrm{~nm}$ wavelength with concentration of $1000 \mathrm{ppm}$, except at $1 \mathrm{ppm}$ concentration whereas highest absorbance at UV B wavelength was at $290 \mathrm{~nm}$ wavelength with concentration of $1000 \mathrm{ppm}$ but there is a difference in absorption intensity at concentrations of $1 \mathrm{ppm}, 10 \mathrm{ppm}$ and $100 \mathrm{ppm}$ in which a maximum wavelength shift occurs at a wavelength of $295 \mathrm{~nm}$. This is called a bathocromic shift which can be caused by the solvent or an auxochromic group present in sample. The absorbance ability of a compound may be affected by the excitation of binding electrons from the nonbonding orbital to the antibonding orbitals, so that the absorbed or absorbed maximum wavelength can be related to the bonds that may be present in a sample. Chromophore group. is a group that plays an important role in the absorption of electromagnetic radiation at UV-Vis wavelengths. While the group aksokrom is a group that has a major effect on the shift of the peak uptake of chromophore groups to a greater wavelength.

The absorbance value obtained from ethanolite extract of jamblang fruit is then calculated its SPF value. Calculation of SPF value is using Petro Equation (1981) This equation can predict the SPF value of a solution by calculating the AUC value divided by the wavelength interval. SPF value data can be seen in figure 4.2 and 4.3. 


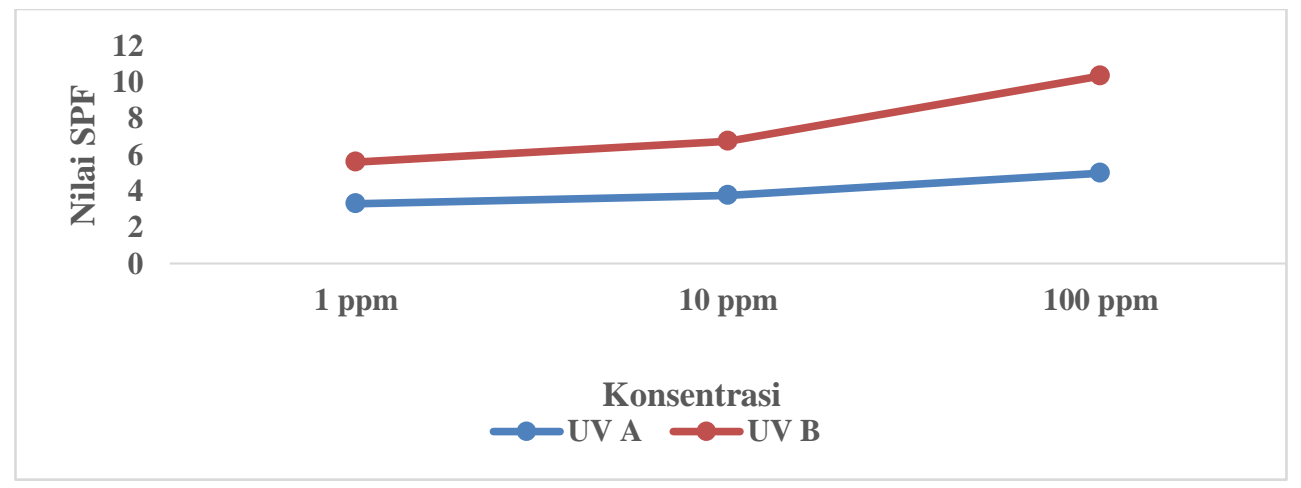

Figure 3:-Graph of SPF Value at UV A and UV B Wavelengths

Calculation of transmittance value obtained at $5 \mathrm{~nm}$ interval from ethanolite extract of fruit jamblang is then calculated value\% Tp at wavelength UV A data, can be seen in appendix table.

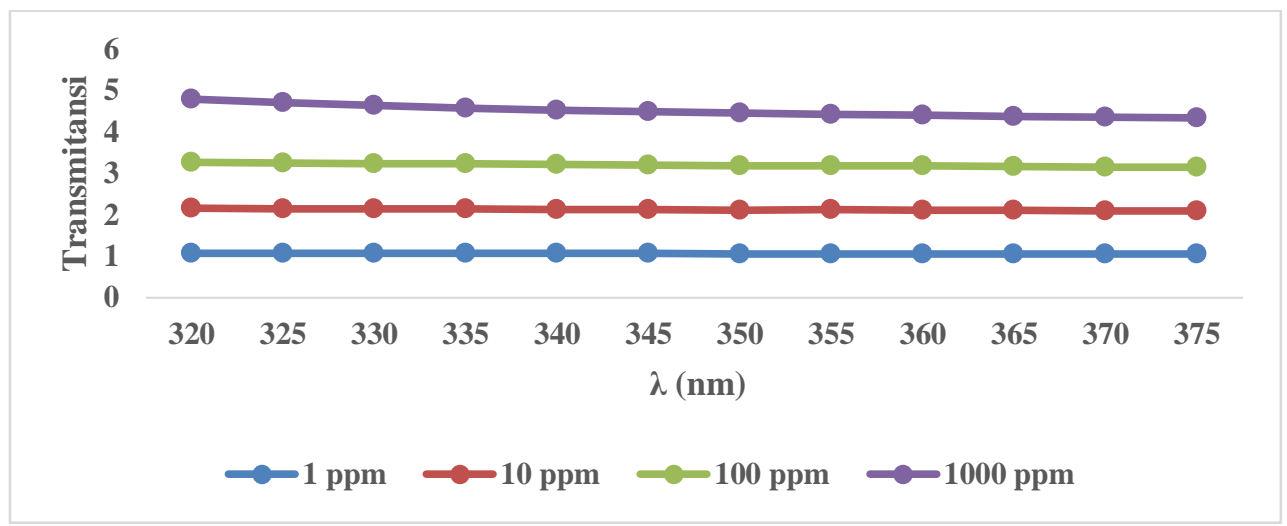

Figure 4:-Graph The transmittance value at UV A wavelength

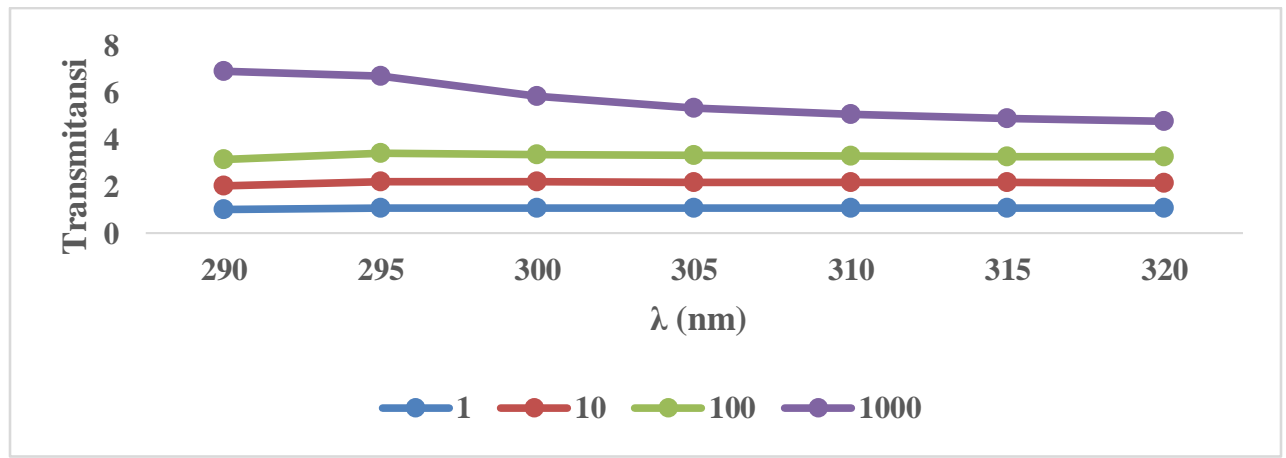

Figure 5:-Graph The transmittance value at UV B wavelength

The transmittance value of Figure 4 and 5 are obtained from converting the absorbance value obtained from the UVvis spectrophotometer method using the $\mathrm{A}=-\log \mathrm{T}$ equation so that it can be concluded that the value of $\mathrm{T}=\operatorname{antilog}$ A. Based on that, it can be concluded that the relationship between absorbance value, transmittance and concentration is the higher the concentration the higher the value of absorbance and transmittance or can be said that the value of absorbance and transmittance are linear with the value of concentration. While the value of transmittance is inversely proportional to the absorbance value where the higher the absorbance the lower the value of transmittance.

Table 2:-Test Results\% Tp At UV A Wavelength

\begin{tabular}{|c|c|c|}
\hline Concentration (ppm) & \%Tp & Category \\
\hline 1 & 1,129 & Sun block \\
\hline
\end{tabular}




\begin{tabular}{|c|c|c|}
\hline 10 & 1,126 & Sun block \\
\hline 100 & 1,138 & Sun block \\
\hline 1000 & 1,142 & Sun block \\
\hline
\end{tabular}

Table 3:-Test Results\% Te At Wavelength UV A

\begin{tabular}{|c|c|c|}
\hline Concentration (ppm) & \% Te & Category \\
\hline 1 & 1,133 & Ultra protection \\
\hline 10 & 1,158 & Ultra protection \\
\hline 100 & 1,232 & Ultra protection \\
\hline 1000 & 2,731 & Ultra protection \\
\hline
\end{tabular}

Table 4:-SPF Test Results At UV A Wavelength

\begin{tabular}{|c|c|c|}
\hline Concetration (ppm) & SPF & Category \\
\hline 1 & 3,311 & Minimum Protection \\
\hline 10 & 3,758 & Minimum Protection \\
\hline 100 & 4,989 & Medium Protection \\
\hline 1000 & 315,5 & Ultra protection \\
\hline
\end{tabular}

Table 5:-SPF Test Results at UV B Wavelength

\begin{tabular}{|c|c|c|}
\hline Concentration (ppm) & SPF & Category \\
\hline 1 & 2,280 & Minimum Protection \\
\hline 10 & 2,979 & Minimum Protection \\
\hline 100 & 5,346 & Medium Protection \\
\hline 1000 & 13.002 & Ultra Protection \\
\hline
\end{tabular}

According to Balsam (1972) and Niekha (2015) a good UV anti-ray agent is an agent with an SPF value of at least 15 , a Tp $\%$ of at least $3 \%$, and a Te $\%$ of at least $<1 \%$. The higher the SPF value, the longer the anti-radiation agent UV can protect the skin from the negative impact. The lower the $\% \mathrm{Tp}$ and the $\% \mathrm{Te}$ values the better the UV-ray agent. In order to see the relationship of concentration with SPF value, the value of $\% \mathrm{Tp}$, and the $\%$ Te value can be seen in figure 2. Thus, this study stated that Jamblang fruit ethanolite extract has potential as a good anti-UV ray agent, which has the potential to absorb and transmit radiation UV is good at UV A and UV B wavelengths.

\section{Conclusion:-}

1. Extract of jamblang fruit ethanolite has effectiveness of UV anti-radiation agent:

2. UV A at concentrations of $1 \mathrm{ppm}, 10 \mathrm{ppm}, 100 \mathrm{ppm}$, and $1000 \mathrm{ppm}$, can transmit UV radiation to the sunblock category and absorb UV Radiation with minimal protection category at $1 \mathrm{ppm}$ and $10 \mathrm{ppm}$, medium protection at $100 \mathrm{ppm}$ and ultra protection at a concentration of $1000 \mathrm{ppm}$.

3. UV B at concentrations of 1 ppm, 10 ppm, 100 ppm, and 1000 ppm can transmit UV radiation under the ultraprotection category and absorb UV radiation with a minimal protective category at concentrations of $1 \mathrm{ppm}$ and $10 \mathrm{ppm}$, medium protection at $100 \mathrm{ppm}$, and ultra protection at a concentration of $1000 \mathrm{ppm}$.

4. The calculation results show that at the wavelength of UV A and UV B with concentration of $1 \mathrm{ppm}, 10 \mathrm{ppm}$, $100 \mathrm{ppm}$, and $1000 \mathrm{ppm}$, obtained\% Tp with a value of $1.129 ; 1,126 ; 1,138 ; 1.142$. Then SPF UV A with a value of $3.311 ; 3,758 ; 4,989 ; 315.5 \%$ Te with a value of $1.133 ; 1,158 ; 1,232 ; 2,731$ and SPF UV B with a value of 2,$280 ; 2,979 ; 5,346$; and 13002 . 


\section{References:-}

1. Balsam, \& Saragin. 1972. Cosmetics: science and technology 2nd ed. Vol. 1-3 : New york.

2. Bahera et.,al. 2012. UV-Visible Spectrophotometric Method Development and Validation of Assay of Paracetamol Tablet Formulation. Journal Analitical and Bioanalitical Tecniques. Vol. 101. No. 2.

3. Charlotte., 2009. Solar Ultraviolet Radiation and Skin Cancer: Accup Med. Vol. 59. Hal. 2-8.

4. Cosmet, Dermtol. 2015. Naturally product for photoprotection.

5. Frans, dkk. 2016. Uji efek ekstrak etanol $96 \%$ anggur merah (vitis vinifera) terhadap penurunan kadar trigliserida pada tikus putih yang diinduksi triton x-100. Biomedic journal. Vol. 8. No. 2. Universitas Muhammadiyah : Surakarta.

6. Jellinek. 1970. Formulation and Funcition Of Cosmetics. Willey inter science: New York.

7. Khopkar, S.M., 1990. Konsep dasar kimia analitik. Penerjemah: A. Soptorahajo. Jakarta: Penerbit Universitas Indonesia. Jakarta.

8. Latha, dkk.2013 Sunscreening Agent. Journal of Dermatology. Departement of farmatology. Azeezia Medical College: India.

9. Lavi, Novita. 2012. Tabir Surya Bagi Pelaku Wisata. Fakultas Kedokteran. Universitas Udayana: Bali.

10. Lia, dkk. 2014. Aktivitas antioksidan daun dan buah jamblang (Syzigium Cumini L.) Skeel). Prosiding Seminar Nasional Penelitian dan PKM Sains. Vol. 4. No. 1. Sekolah Tinggi Ilmu Farmasi: Bandung.

11. Mohrig, Jerry.R. 2010. Techniques in organic chemistry (3and ed): New York. WH Freeman and Company.

12. Mustafa, dkk. 2014. Efek radiasi UV pada spektrum korneum kulit tikus. Siencedirect. Vol. 7 Gazi University: Turkey.

13. Niekha. 2015. Uji Stabilitas Fisik dan Penentuan Nilai SPF Krim Rice Bran Oil. Fakultas Kedokteran dan Ilmu Kesehatan. Farmasi. Uin Syarif Hidayatullah: Jakarta.

14. Nuverry, Ambo. 2012. Sintesis senyawa 4-(4-hidroksi-3-metoksifenil)-3-buten-2-on dengan katalis basa serta uji potensinya sebagai tabir surya. Thesis. Universitas Negeri Yogyakarta: Yogyakarta.

15. Petro, A.J. 1981. Correlation Of Spectrophotometric With Sunscreen Protection Factors, International Journal Of Cosmetic Science. Hal. 185-196.

16. Prasidda. dkk. 2016. Potensi senyawa bioktif rambut jagung (zea Mays L.) untu k tabir surya. Jurnal Pangan dan Argoindustri. Vol. 4. No. 1.Universitas Brawijaya: Malang.

17. Purwaningsih. dkk. 2015. Efek fotoprotektif krim tabir surya dengan penambahan kerangginan dan buah bakau hitam (Rhizopora Mucronata Lamk.). Jurnal ilmu dan teknologi kelautan tropis. Vol. 7. No. 1. IPB : Bogor.

18. Rini. Dkk. 2014. Pengaruh intensitas waktu paparan sinar ultraviolet-C terhadap kornea mencit (Mus Musculus L.). Medical Journal Of Lampung University. Vol. 3. No. 5. Universitas Lampung: Bandar Lampung.

19. Sari, Ayu. 2015. Antioksidan alternatif untuk menangkal bahaya radikal bebas pada kulit. Journal Of Islamic Sceince and Tecnology. Vol. 1. No. 1. Universitas Negeri Ar-Raniry: Banda Aceh.

20. Susanti, Dkk. 2012. Aktivitas perlindungan sinar UV kulit Garcia Mangostana Linn secara in-vitro. Pharmaceutical Journal of Indonesia. Vol. 13. No. 2. Universitas Muhamadiah Surakarta: Surakarta.

21. Yayu, Zuriyati. 2016. Keanekaragaman Sumbe Daya Genetic Tanaman Buah-Buahan Eksotik Di Kabupaten Bintan Provinsi Kepulauan Riau. Bul. Plasma Nutffah. No. 22. Vol. 1 Hal. 11-20. 